J. Japan. Assoc. Min.

Petr. Econ. Geol.

75, $44-54,1980$

\title{
CRYSTALLIZATION TREND OF CHROMIAN SPINEL IN SOME ALKALI BASALTS AND CALC-ALKALI ANDESITES FROM JAPANESE ISLAND
}

\author{
Takashi nagao, Masatsugu Yamamoto \\ and Kosuke ONuma \\ Department of Geology and Minevalogy, Hokkaido University, Sapporo, 060, Japan
}

\begin{abstract}
Chromian spinels in the alkali basalts from the Misasa district, western Honshu, and also in the calc-alkali andesites from the Chokai volcano, northeastern Honshu, have been analysed as well as thcir host rocks. These spinels are the most aluminous yet reported from the island arc volacnic rocks except those from xenoliths, and the $\mathrm{Cr} /(\mathrm{Cr}+\mathrm{AI})$ ratio ranges $0.255-0.592$ and $0.173-0.668$ in the Misasa spinel and the Chokai spinel, respectively. When the compositions of spinels plot in terms of $\mathrm{C}_{\mathrm{T}-\mathrm{Al}}-\mathrm{Fe}^{3+}$ the crystallization trends proceed from $\mathrm{Cr}$ - Al rich portion towards $\mathrm{Fe}^{3+}$ corner associated with an increase in the $\mathrm{Cr} /(\mathrm{Cr}+\mathrm{Al})$ ratio. On the basis of these data together with those from published papers, it is concluded that the composition of spinel is controlled by the chemistry of host magma as well as pressure, and therefore that it is rather inadequate to compare the depth of crystallization of magma at early stage in different provinces to each other in terms of the $\mathrm{Al}_{2} \mathrm{O}_{3}$ content of chromian spincl.
\end{abstract}

\section{INTRODUGTION}

The chemistry of spinel is governed by the bulk chemistry, temperature, pressure, and oxygen fugacity of a magma from which the spinel crystallizes out (Irvine, 1965, 1967; Thompson, 1973; Hill and Roeder, 1974; Haggerty, 1977, 1979; Shiraki et al., 1979). Because of this, it is rather difficult to establish the role of spinel in the generation and differentiation of magma.

Only a few reports were published on the chemical compositions of spinels in the volcanic rocks from the Japanese islands; in the picrite basalt from Mineoka, central Japan (Tazaki, 1975), in the boninite from Chichijima, Ogasawara islands (Kuroda and Shiraki, 1975), in the basanitoid from Nanzaki, central Japan (Shiraki et al., 1979).

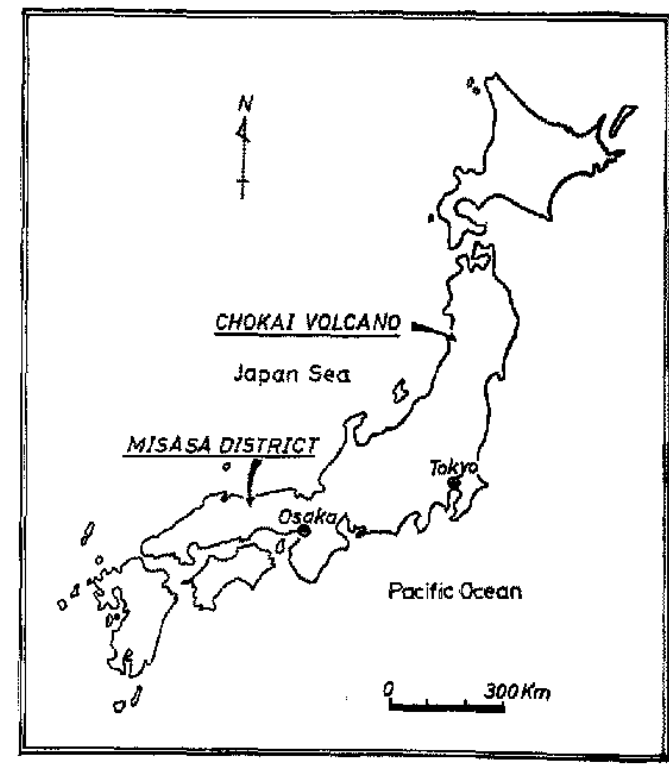

Fig. 1. Index map.

(Manuscript received August 1, 1979) 
In addition to these spinels, Aoki and Prinz (1974) reported the chemical compositions of chromian spinels in the ultramafic inclusions from Itinome-gata, northeastern Honshu, Japan.

In this paper we describe the mode of occurrence and the chemical compositions of chromian spinels both in the alkali basalts from the Misasa district, western Honshu, and in the calc-alkali andesites from Chokai volcano, northeastern Honshu (Fig. 1), and discuss briefly their crystallization trends in relation to the host rocks.

\section{DESCRIPTION OF HOST ROCKS}

\section{Misasa alkali basalts}

The basalts in the Misasa district erupted in Pliocene time, consist of two basalt series formed by the crystallization differentiation of an alkali basaltic magma; one is Kamejiri basalt series and the other Sakamoto basalt series (Nagao, 1978).

The Kamejiri basalt series is further divided into the three units $\mathrm{KB1}, \mathrm{KB} 2$, and KB3 from the stratigraphical and petrographical view point. The chemistry of constitutent minerals changes reguarly in each unit.

The host rocks of the present spinels are the Kamejiri basalt $\mathrm{KB} 2$ and $\mathrm{KB} 3$ and the Sakamoto Sbasalt SB2 and SB3. Their bulk chemical compositions are given in Table 1. The Kamejiri basalt is porphyritic olivine basalt or olivine-clinopyroxene basalt and includes olivine and plagioclase or olivine, clinopyroxene and plagioclase as phenocrysts, respectively. Both groundmasses consist of olivine, clinopyroxene, plagioclase, and iron-titanium oxide. All the chromian spinels are included in the phenocrystic olivine. The olivine shows zoning and its composition ranges from
Table 1. Chemical analyses of volcanic rocks.

\begin{tabular}{|c|c|c|c|c|c|c|}
\hline & $(1)^{x}$ & $(2)^{*}$ & (3) & $(4)^{n}$ & (5) & (5) \\
\hline $\mathrm{SiO}_{2}$ & 49.81 & 49,15 & 51,24 & 52.04 & 53.03 & 61.20 \\
\hline $\mathrm{TiO}_{2}$ & 1.88 & 1.68 & 1.27 & 2.01 & 0.48 & 0.63 \\
\hline $\mathrm{Al}_{2} \mathrm{O}_{3}$ & 16.37 & 19.10 & 16.91 & 17.59 & 18.21 & 16.80 \\
\hline $\mathrm{Fe}_{2} \mathrm{O}_{3}$ & - & 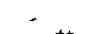 & 4,69 & - & 3.69 & 3.54 \\
\hline$F=0^{2}$ & $8.73^{* \star}$ & $8.37^{+* \pi}$ & 5.51 & $9.05^{k k}$ & 4.35 & 3.53 \\
\hline $\mathrm{MnO}$ & 0.35 & 0.30 & 0.14 & 0.30 & 0.73 & 0.73 \\
\hline $\mathrm{MgO}$ & 7.51 & 5.98 & 5.81 & 5.28 & 6.09 & 2.82 \\
\hline C80 & 10.35 & 11.06 & 3.19 & 8.09 & 7.73 & 5.78 \\
\hline $\mathrm{Na}_{2} \mathrm{O}$ & 3.62 & 3.32 & 3.16 & 3.83 & 2.83 & 3.75 \\
\hline $\mathrm{K}_{2} 0$ & 1.19 & 0.54 & 1.98 & 0.89 & 1.27 & 2.10 \\
\hline $\mathrm{P}_{2} \mathrm{O}_{5}$ & n.d. & i.d. & 0.49 & n.d. & 0.75 & 0.28 \\
\hline $\mathrm{H}_{2} \mathrm{O}^{+}$ & - & - & 0.51 & - & 0.85 & 0.31 \\
\hline $\mathrm{H}_{2} \mathrm{O}-$ & - & - & 0.35 & - & 0.75 & 0.70 \\
\hline TotaT & 99.81 & $\$ 9: 50$ & 100.25 & 99.08 & 99.56 & 100.17 \\
\hline
\end{tabular}

1. olivine basalt, Kamejiri basalt series (IKB2-a),

2. olivine-clinopyroxene basalt, Kamejiri basalt series (KB3-a),

3. olivine basalt, Sakamoto basalt series (Takamura, 1973).

4. olivine-clinopyroxene basalt, Sakamoto basalt series (SB2),

5. hornblende bg. olivine-hypersthene-augite andesite, Chokai volcano (Onuma, 1963b),

6. olivine bg. hornblende-hypersthene-augite andesite, Chokai volcano (Onuma, 1963b).

$\mathrm{Fo}_{86}$ (core) to $\mathrm{Fo}_{63}$ (margin).

The Sakamoto basalt is olivine basalt, olivine-augite basalt, or aphyric basalt and contains olivine and plagioclase or olivine, clinopyroxene, and plagioclase. The groundmass consists of olivine, clinopyroxene, plagioclase, and iron-titanium oxide, but in the aphyric basalt orthopyroxene is also present. All the chromian spinels are included in the olivine which is distinctly zoned, ranging from $\mathrm{FO}_{\mathrm{B4}}$ to $\mathrm{Fo}_{66}$.

\section{Chokai calc-alkali andesite}

Chokai volcano consists of West and East volcanoes. High-alumina? basalts and calc-alkali andesites occur in this volcano, and the calc-alkali andesites are divided into two types: one is hornblende-bearing type distributed in the West volcano and the 
other hornblende-free type mainly distributed in the East volcano (Onuma, 1963a, b).

In this study the chromian spinels both in the most basic rock (hornblende-bearing olivine-pyroxene andesite) and the most acidic rock (olivine-bearing homblende andesite) among the hornblende-bearing type rocks were analysed. The bulk chemistry of these host rocks is given in Table 1 .

The hornblende-bearing olivine pyroxene andesite (Table 1c-1 in Onuma, 1963b) carries a considerable amount of phenocrysts consisting of plagioclase, clinopyroxene, orthopyroxene, less amounts of olivine and iron-titanium oxide, and rare hornblende. The groundmass consists of plagioclase, clinpyroxene, orthopyroxene, and irontitanium oxide. The spinels analysed are included in the phenocrystic olivine with the composition of about $\mathrm{Fo}_{84}$.

The olivine-bearing hornblende andesite (Table 1c-9 in Onuma, 1963b) is porphyritic and contains homblende with opacite rim, clinopyroxene, orthopyroxene, and anhedral olivine. The groundmass is hyalocrystalline and consists of plaigoclase, clinopyroxene, orthopyroxene and iron-titanium oxide with subordinate amounts of silica mineral as well as glass. Glomeroporphyritic aggregates, consisting mostly of euhedral-subhedral olivine with less amounts of spinel, orthopyroxene, clinopyroxene, plagioclase and hornblende are observed.

The spinels analysed have two types of mode of occurrence: greenish-brown euhedral spinels up to $20 \mu$, are included in the phenocrystic olivine with $\mathrm{Fo}_{85}$, and in the

Table 2. Selected microprobe analyses of spinels.

\begin{tabular}{|c|c|c|c|c|c|c|c|c|c|c|c|c|}
\hline & (1) & (2) & $(3)$ & (4) & (5) & (6) & (7) & (A) & (9) & $\{10\}$ & (11) & (12) \\
\hline $\mathrm{SiO}_{2}$ & n.d. & n.d. & n.t. & n.d. & n.d. & n.d. & 0.11 & 0.07 & 0.10 & - & 0.05 & 0.10 \\
\hline $\mathrm{T}^{1} \mathrm{O}_{2}$ & 0.60 & 1.88 & 1.01 & 0.99 & 3.61 & 12.07 & 0,40 & 0.44 & 0.39 & - & 5.79 & 7.45 \\
\hline $\mathrm{Al}_{2} \mathrm{O}_{3}$ & 40.77 & 25.11 & 34.50 & 33.57 & 24.09 & 3.27 & 33.91 & 41.19 & 44.70 & 43.40 & S. 97 & 4.82 \\
\hline $\mathrm{Fe}_{2} \mathrm{O}_{3}$ & 4.88 & $9.4 B$ & 7,69 & 9.70 & 19.02 & 39.79 & 13.19 & 10.12 & 5.79 & 12.41 & 38.95 & 43.74 \\
\hline $\mathrm{Cr}_{2} \mathrm{O}_{3}$ & 20.85 & 29.95 & 24.35 & 23.90 & 18.58 & 3.44 & 21.01 & 17.83 & 15.13 & 13.56 & 12.76 & 6.56 \\
\hline Feo & 18.15 & 19.10 & 17.59 & 17.84 & 23.55 & 35.20 & 17.29 & 13.65 & 14.87 & 18.58 & 31.71 & 33.50 \\
\hline Mrio & 0.13 & 0.29 & 0.10 & 0.70 & 0.23 & 0.44 & 0,31 & 0.11 & 0.13 & 0.23 & 0.34 & 0.48 \\
\hline MgO & 3.21 & 11.27 & 13.36 & 12.98 & 9.28 & 4.39 & 12.98 & 16.38 & 16.01 & 13.33 & 3.50 & 3.26 \\
\hline Tatai & 9 & 97.08 & $\overline{9 B .32}$ & 99.08 & $97 . \overline{36}$ & 98.54 & $99 . \overline{20}$ & 99.79 & 100.10 & 101.51 & $\overline{99.07}$ & 99.91 \\
\hline $\mathrm{Cr} /(\mathrm{Cr}+\mathrm{A} 1)$ & 0.255 & 0.444 & 0,327 & 0.341 & 0.328 & 0.418 & 0.294 & 0.225 & 0.785 & 0.173 & 0.589 & 0.477 \\
\hline $\mathrm{Fe}^{3+} /\left(\underset{\left.\mathrm{Fe}^{3+}\right)}{(\mathrm{C}+\mathrm{A})+}\right.$ & 0.054 & 0.718 & 0.388 & 0.239 & 0.110 & 0,822 & 0.149 & 0.100 & 0.093 & 0.131 & 0.631 & 0.752 \\
\hline $\mathrm{Mg} /(\mathrm{Mg}+\mathrm{Fe})$ & 0.565 & 0.513 & 0.572 & 0.413 & 0.558 & 0.182 & 0.572 & 0.683 & 0.657 & 0.561 & 0.164 & 0.148 \\
\hline
\end{tabular}

*: $\mathrm{FB}_{2} \mathrm{O}_{3}$ ware calculated essuffing stoichiametry.

1. olivine-clinopyroxene basalt, Kamejiri basalt series (KB2-c),

2. olivine basait, Kamejiri basalt series (KB2-a),

3. olivine basalt, Sakamoto basalt series (SB3).

4. olivine basalt, Sakamoto basalt series (SB3),

5. olivine-clinopyroxene basalt, Sakmoto basalt series (SB2),

6. olivine-clinopyroxene basalt, Sakamoto basalt series (SB2),

7. hornblende bg. otivine-hypersthene-augite andesite, Chokai volcano,

8. hornblende-bg. olivine-hypersthene-augite andesite, Chokai volcano,

9. hornblende-bg, olivine-hypersthene-augite andesite, Chokai volcano,

10. olivine-bg. hornblende-hypersthene-augite andesite, Chokai volcano,

11. olivine-bg. hornblende-hypersthene-augite andesite, Chokai volcano,

12. olivine-bg. hornblende-hypersthene-augite andesite, Chokai volcano.

1-6: analyst T. Nagao, 7-12: analyst M. Yamamoto. 


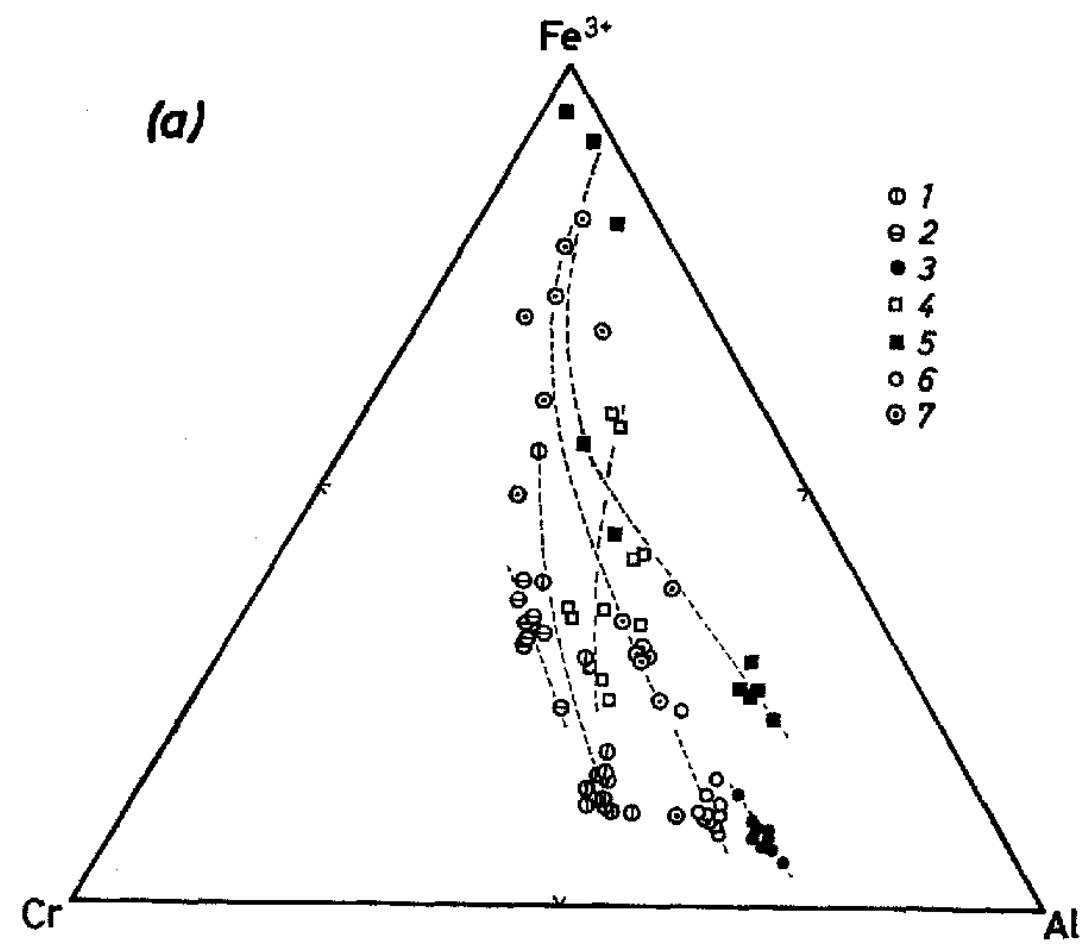

Fig. 2.-(a) $\mathrm{Cr}-\mathrm{Al}-\mathrm{Fe}^{8+}$ diagram of spinels

Misasa spinels: 1. divine basalt, Kamejiri basalt series (KB2-a), 2. clinopyroxere-olivine basalt, Kamejiri basalt series (KB2-b),

3. olivine-clinopyroxene basalt, Kamejiri basalt series (KB2-c),

4. olivine-clinopyroxene basalt, Kamejiri basalt series (KB3-a),

5. olivine-clinopyroxene basalt, Kamejiri basalt series (KB3-b), 6. olivine basalt, Sakamoto basalt series (SB3), 7. olivine clinopyroxene basalt. Sakamoto basalt series (SB2).

other case dark brown anhedral spinels, 240 $\times 150-350 \times 160 \mu$, with distinct zoning are present in the interstices between olivine grains in the glomeroporphyritic aggregates.

\section{Chemistry and Crystallization TREND OF SPINEL}

Chemical analyses were carried out using the electron microprobe, JXA-5A (Inst. for Thermal Spring Research, Okayama Univ.) and JSM-50A (Government Industrial Development, Hokkaido), and the correction is made by the method of Bence and Albee (1968).

\section{Spinels in the Misasa alkali basalt}

Chromian spinels both in the Kamejiri basalt and the Sakamoto basalt are euhedral and included in the olivine phenocrysts. They are less than $10 \mu$, and dark reddishbrown in the core of olivine and are opaque in the margin. The main components of analysed specimens range as follows: $\mathrm{TiO}_{2}$ $0.55-12.57 \%, \quad \mathrm{Al}_{2} \mathrm{O}_{3} \quad 3.10-40.77 \%, \quad \mathrm{Fe}_{2} \mathrm{O}_{8}$ $4.88-38.05 \%$, $\mathrm{FeO} 13.02-39.21 \%$, MgO 1 . $91-19.42 \%, \mathrm{Cr}_{2} \mathrm{O}_{3} 3.44-31.16 \%$. The selected chemical analyses by the microprobe are listed in Table 2.

The spinels in the Sakamoto basalt formed by the crystallization at early 


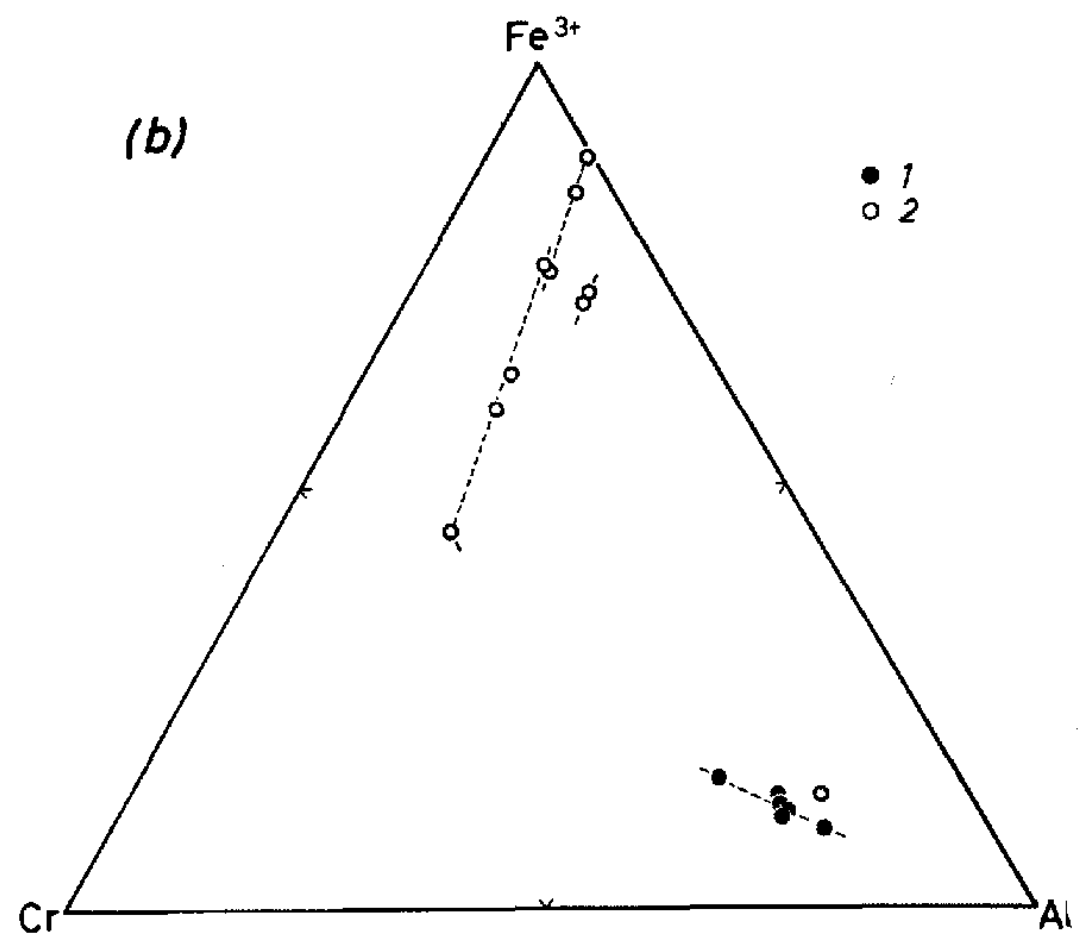

Fig. 2,-(b) Chokai spinels: 1. hornblende-bg. olivine-hypersthene-augite andesite, 2. olivinc-bg. hornblende-hypersthene-augite andesite.

stage and those in xenocrystic olivine in the Kamejiri basalt (KB2-c) have almost same composition and are clustered in the narrow area as shown in Fig. 2a, whereas the spinels in the other rocks have a wide range in composition: the $\mathrm{Fe}^{8+} /\left(\mathrm{Cr}+\mathrm{Al}+\mathrm{Fe}^{3+}\right)$ ratio becomes progressively higher from the core $(0.054)$ to the margin $(0.822)$. The $\mathrm{TiO}_{2}$ content increases with increasing $\mathrm{Fe}^{3+}$.

Fig. 2a shows the plots of spinels in the $\mathrm{Cr}-\mathrm{Al}-\mathrm{Fe}^{3+}$ diagram. It clearly shows that the trends of compositional variation of spinels proceed from the $\mathrm{Cr}-\mathrm{Al}$ region (chromian spinel) twoards $\mathrm{Fe}^{3+}$ corner (magnetite) associated with a little increase in the $\mathrm{Cr} /(\mathrm{Cr}+\mathrm{Al})$ ratio, and the trends are nearly parallel from specimen to specimen; in other words the spinels become high in the $\mathrm{Fe}^{3+} /\left(\mathrm{Cr}+\mathrm{Al}+\mathrm{Fe}^{3+}\right)$ ratio as the crystallization proceeds, because these trends correspond to the compositional change of the host olivine from the Fo-rich core to the Fo-poor margin.

2. Spinels in the Chokai calc-alkali andesite.

The spinels having different modes of occurrence were analysed and the selected analyses are listed in Table 2; one is included in the olivine phenocrysts and the other occurs as a glomeroporphyritic mineral.

The analysed spinels in the hornblendebearing olivine pyroxene andesite are euhedral, dark reddish-brown, and included in the olivine phenocryst. The main components range as follows: $\mathrm{TiO}_{2} 0.33-0.44 \%$, $\mathrm{Al}_{2} \mathrm{O}_{3} \quad 33.91-44.70 \%, \quad \mathrm{Fe}_{2} \mathrm{O}_{3} \quad 8.79-13.19 \%$, $\mathrm{Cr}_{2} \mathrm{O}_{3} \quad 15.11-21.01 \%$, FeO 13.65-17.79\% $\mathrm{MgO}$ 12.98-16.38\%. These spinels are probably the most aluminous yet reported except those in xenolith. As shown in Fig. 
2b the $\mathrm{Fe}^{3+}$ content slightly increases with decreasing $\mathrm{Al}$ content.

The spinels in the olivine phenocryst in the olivine-bearing hornblende andesite have the similar mineralogical feature and chemistry with those in the former andesite. On the other hand, the spinels occurring as glomeropoprhyritic minerals are relatively large in size, opaque and show distinct zoning. The main components range as follows: $\mathrm{TiO}_{2} 4.92-7.92 \%, \quad \mathrm{Al}_{2} \mathrm{O}_{3} 4.31-7.79 \%, \mathrm{Fe}_{2}$ $\mathrm{O}_{3} .29 .92-41.85 \%, \mathrm{Cr}_{2} \mathrm{O}_{3} 6.04-23.35 \%, \mathrm{FeO}$ $29.63-34.24 \%$, MgO 2.55-4.43\%.

From the plots in Fig. $2 b$ it can be understood that although the spinels representing the middle stage have not yet been found, in the crystallization trend the Chokai spinel increases in the $\mathrm{Cr} /(\mathrm{Cr}+\mathrm{Al})$ ratio associated with the increase of $\mathrm{Fe}^{3+}$
$\left(\mathrm{Cr}+\mathrm{Al}+\mathrm{Fe}^{3+}\right)$ ratio at relatively early stage and then increases distinctly in the $\mathrm{Fe}^{3+} /\left(\mathrm{Cr}+\mathrm{Al}+\mathrm{Fe}^{3+}\right)$ ratio at later stage with nearly constant $\mathrm{Cr} /(\mathrm{Cr}+\mathrm{Al})$ ratio, reflecting the concentration of iron in the host liquid at the middle to later stage.

\section{Discussion}

The spinels reported in this study occur in the different type of rocks, alkali basalt containing 49.15-52.04 wt. $\% \mathrm{SiO}_{2}$ and calcalkali andesite of which the $\mathrm{SiO}_{2}$ content ranges $53.02-61.20 \mathrm{wt} . \%$.

The study on the chemical compositions of spinels in spinel lherzolite and plagioclase lherzolite revealed that when the bulk chemistry of host rock remains constant the $\mathrm{Cr} /(\mathrm{Cr}+\mathrm{Al})$ ratio in spinel decreases with increasing pressure (Irvine, 1967; Haggerty,

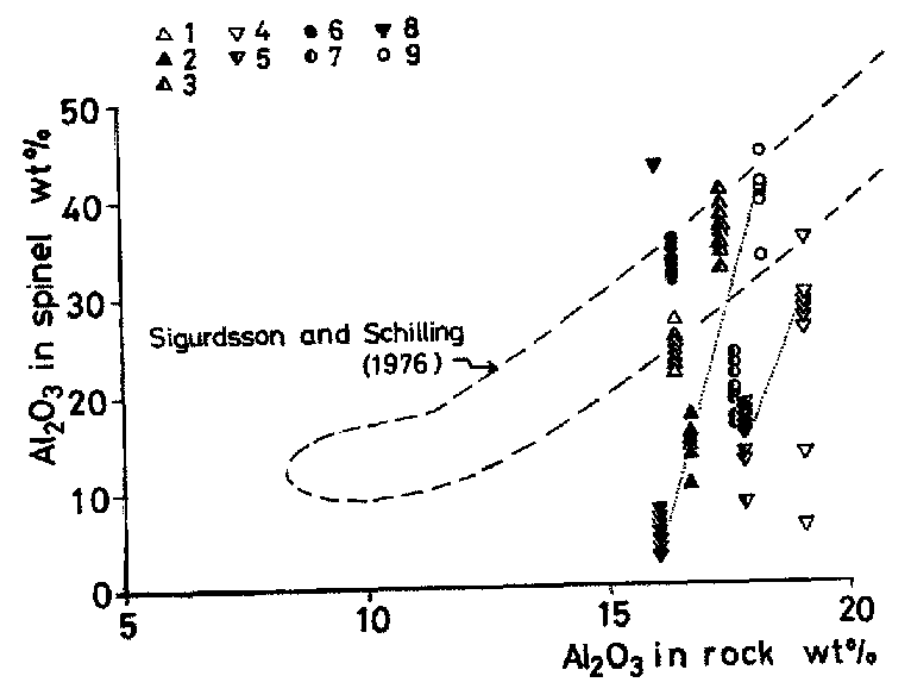

Fig. 3. Plot of $\mathrm{Al}_{2} \mathrm{O}_{3}$ content in spinels versus $\mathrm{Al}_{2} \mathrm{O}_{3}$ content of whole rock. 1. olivine basalt, Kamejiri basalt series (KB2-a), 2. clinopyroxeneolivine basalt, Kamejiri basalt series $(\mathrm{KB} 2-\mathrm{b})$, 3. olivine-clinopyroxene basalt, Kamejiri basalt eries (KB2-c), 4. olivine-clinopyroxene basalt, Kamejiri basait series (KB3-a), 5. olivine-clinopyroxene basalt, Kamejiri basalt series (KB3-b), 6. olivine basalt, Sakamoto sbaalt series (SB3), 7. olivine-clinopyroxene basalt, Skamoto basalt series (SB2), 8. hornblende-bg. olivine-hypersthene-augite andesite, Chokai volcano, 9. olivine-bg. hypersthene-augite andesite, Chokai volcano. 


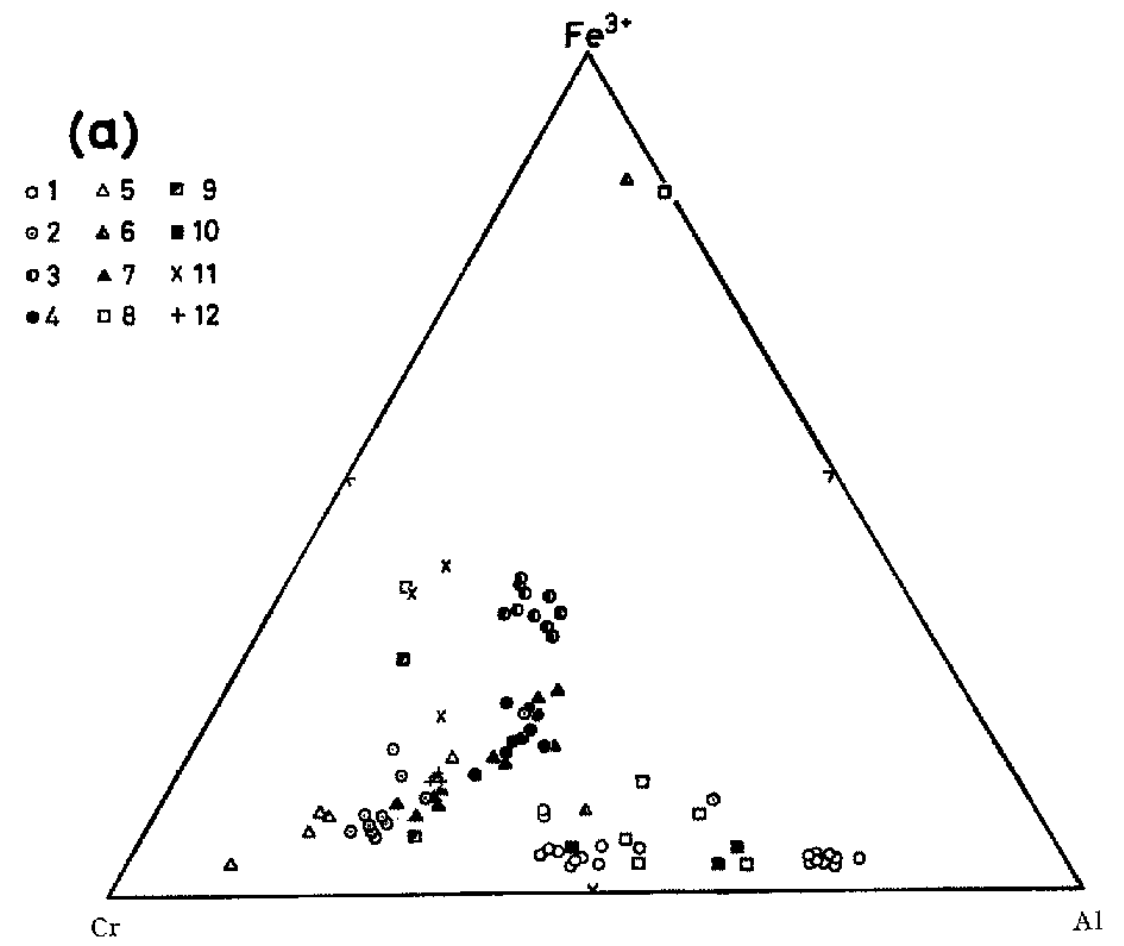

Fig. 4.-(a) Cr- $\mathrm{Al}-\mathrm{Fe}^{\mathrm{y}}+$ diagram of spinels in volcanic rocks from various localities. non-alkaline volcanic rocks: 1. Mid Atlantic Ridge basalt (Sigurdsson and Schilling, 1976), 2. Guam calc-alkali basalt (Shiraki et al., 1977), 3. Snake River Plain basalt (Thompson, 1973), 4. Guam tholeiite (Shiraki et al., 1977), 5. boninite (Kuroda and Shiraki, 1975), 6. Thingumuli tholeiite (Carmichael, 1967), 7. Mineoka picrite basalt (Tazaki, 1975), 8. Leg 6 basalt (Ridley et al., 1974), 9. sanukite (Sato, 1977), 10. submarine basalt (Bryan, 1972), 11. prehistoric Makaopuhi tholeite (Evens and Moore, 1968), 12. Kilauea and Makaopuhi basalt (Evans and Wright, 1972).

1977, 1979; etc.). In their experimental study on the melting of lunar rocks at high temperature and pressure, Green et al. (1971, 1972) also found that the $\mathrm{Cr} /(\mathrm{Cr}+\mathrm{Al})$ ratio of liquidus and near liquidus spinel decreases with increasing pressure.

Based on these facts, Ridley et al. (1974) and Shiraki et al. (1979) inferred that aluminous spinel in abyssal basalt and basanitoid crystallized under the condition of relatively high pressure.

On the other hand, Sigurdsson and Schilling (1976), in the study on Mid-Atlantic Ridge basalt, compiled the chemical com- positions of spinels and their host rocks in an attempt at explaining that the composition of the spinel is controlled by bulk chemistry of host rock, and found that the $\mathrm{Al}_{2} \mathrm{O}_{3}$ content in the spinel increases with an increase in the $\mathrm{Al}_{2} \mathrm{O}_{3}$ in the host rock (Fig. 3). Steele (1972) also explained that a highly aluminous spinel in the clastic rock from Apollo 14 reflects the high aluminous characteristics of host melt. This explanation was comfirmed by Nehru et al. (1974) who found that the spinels in high-alumina basalt from Apollo 15 Rake samples are considerably high in the $\mathrm{Al}_{2} \mathrm{O}_{8}$ content. 


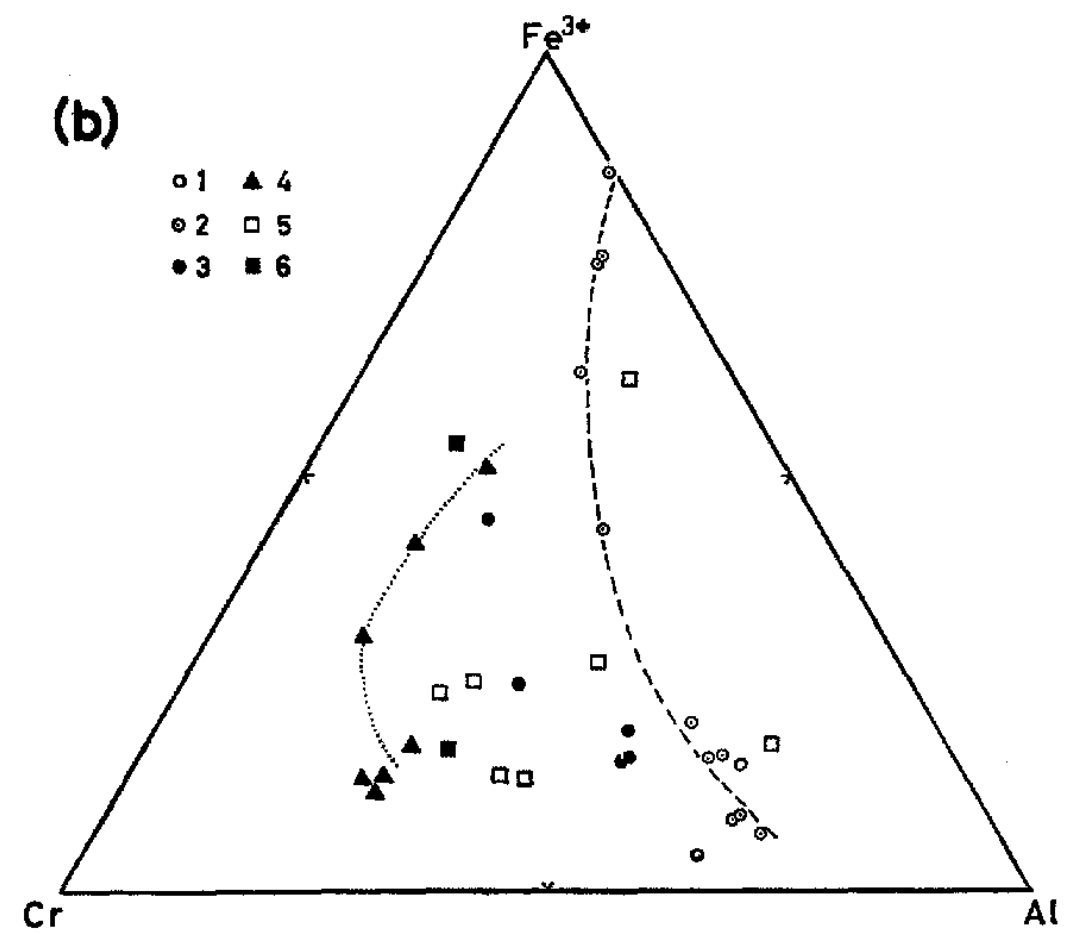

Fig. 4,-(b) alkali volcanic rocks: 1. Monistrol d'Allier alkali basalt (Babkine et a1., 1965), 2. Nanzaki basanitoid (Shiraki et a1., 1979), 3. Leg 17 alkali olivine basalt (Myers et al, 1975), 4. East Island aceanite (Gunn et al., 1970), 5. Grenada basanite (Aтculus, 1974, 1978), 6. Utah aikali olivine basalt (Lowrder, 1973).

A similar phenomenon is also observed in the present study. The host rock carrying highly aluminous spinels in the Chokai volcano is considered to be derived from the high-alumina basalt magma (Onuma, 1964) and contains $\mathrm{Al}_{2} \mathrm{O}_{3}$ as much as 19.66 $\%$.

Shiraki et al. (1979) pointed out, on the basis of the relationship between the compositions of spinels and the $\mathrm{SiO}_{2}$ content of their host rocks from the Izu-Mariana Islands, that the spinels with low Cr/AI ratio tend to occur in the host rocks with low $\mathrm{SiO}_{2}$ content.

The $\mathrm{Cr} /(\mathrm{Cr}+\mathrm{Al})$ ratios of the most aluminous chromian spinel in the Misasa district and the Chokai volcano are 0.218 and 0.185 , respectively. These values are lower than those of chromian spinels in the abyssal basalt (0.33-0.71) reported by Ridley et al. (1974) and in the basanitoid $(0.26-0.30)$, reported by Shiraki et al. (1979) and rather similar to those of spinels in spinel lherzolite, plagioclase lherzolite, and mafic and ultramfic inclusion or megacryst in alkali basalt. If, as has been stated by several workers, the $\mathrm{Cr} /(\mathrm{Cr}+\mathrm{Al})$ ratio in spinel was mainly controlled by pressure, the spinels in the alkali basalt from the Misasa district and in the calc-alkali andesite from the Chokai volcano would crystallize in the upper mantle or as at least in the lower crust.

However, when we apply the chemistry of spinel to petrogenesis, it is rather significant to elucidate the composition of liquid. 
with which spinel is in equilibrium at a certain depth than to merely discuss the depth at which spinel crystallizes. Even if the spinels in rocks from different petrographic province, such as abyssal basalt from oceanic basins, basanitoid from the Izu-Mariana Islands, alkali basalt from the Misasa district, and calc-alkali andesite from the Chokai volcano, have the same $\mathrm{Al}_{2} \mathrm{O}_{3}$ content, it does not ecessarily mean that these spinels crystallized at the same depth, because the liquids which are in equilibrium with the spinels are possibly generated at different depth in the different provinces. Therefore, it may be stated that, when the chemical composition of magma from which the spinels crystallize remains constant, the spinel formed at different pressure may have different composition, while the spinels that crystallize from the magma having different bulk chemistry have different chemistry. Consequently, it is not probable to estimate the depth at which spinel crystallized by merely the comparison of the chemistry of spinels from the different provinces.

Furthermore, Fig. 2a shows that in the Misasa spinels $\mathrm{Al}^{3+}$ increases at early stage and decreases at middle to later stage with increasing $\mathrm{Fe}^{3+}$ (same as in the $\mathrm{Cr} /(\mathrm{Cr}+\mathrm{Al}$ ) ratio). This is not due to the change of pressure but the change of composition of host liquid by fractional crystallization.

We have examined the relation between the $\mathrm{Al}_{2} \mathrm{O}_{3}$ contents in the Misasa and Chokai spinels and those in their host rocks by the same method as described by Sigurdsson and Schilling (1976) (Fig. 3). The spinels in the host rocks formed at relatively early stage plot in the area proposed by Sigurdsson and Schilling. On the other hand, although the spinels in the more differentiated rocks plot outside this area, the Chokai and Misasa KB3 spinels have a similar trend to that of Sigurdsson and Schilling. This indicates that their conclusion holds for the present spinels.

As mentioned earlier, based on the analyses of spinels from the Izu-Mariana Islands, Shiraki et al. (1979) discussed that the $\mathrm{Cr} /(\mathrm{Cr}+\mathrm{Al})$ ratio in spinel increases with an increase in the $\mathrm{SiO}_{2}$ content of magma. Contrary to their discussion, however, as will be understood from Figs. $4 a$ and $b$, the plots of spinels from silica-saturated and under-saturated rocks are over-lapped to each other, and therefore this relation does not always hold for in other provinces. They also pointed out that the composition of spinel is governed by the $\mathrm{H}_{2} \mathrm{O}$ content in magma. However, comparing the Misasa alkali basait and the Chokai calc-alkali andesite; which have the spinel of the same $\mathrm{Al}_{2} \mathrm{O}_{3}$ content, we estimate that the Choaki andesite containing pargasite is more hydrous than the Misasa basalt. Therefore the relationship between the $\mathrm{Al}_{2} \mathrm{O}_{3}$ content of spinel and the $\mathrm{H}_{2} \mathrm{O}$ content in magma should be carefully discussed.

In their experimental study Hill and Roeder (1974) showed that the $\mathrm{Cr}_{2} \mathrm{O}_{3}$ content in magma gives some effect on the stability of spinel. Varne and Brown (1978) considered that the spinels with high $\mathrm{Cr}$ / $\left(\mathrm{Cr}+\mathrm{Al}+\mathrm{Fe}^{\mathrm{s}+}\right)$ ratio in the Adamsfield ultramafic complex, which was formed as a cumulate product crystallized from a tholeiitic or andesitic magma rich in magnesium and poor in taitanium at low pressure, reflect the feature of the magma which is rich in chromium. We must take this fact into account in the consideration of the crystallinzation of spinel.

In this study we attempted to elucidate the main factors that control the composition of spinel on the basis of the analyses 
of spinel by us together with the published data and ideas by several investigators. Although our attempt is not successful, at least it can be said that the composition of spinel is controlled by the effect of the chemistry of host magma as well as pressure and therefore that it is rather inadequate to compare the depth of crystallization of magma at early stage in different provinces to each other merely in terms of the $\mathrm{Al}_{2} \mathrm{O}_{3}$ content of spinel. Further experimental and petrochemical studies are expected to throw light on the problem.

\section{ACKNOWLEDGEMENT}

Prof. Y. Katsui of Hokkaido Univ. consistently encouraged us and read the manuscript, Prof. K. Yagi of the same university critically read the paper, Drs. K. Tazaki of Inst. for Thermal Spring Research, Okayama Univ. and Y. Suzuki of Government Industrial Development Labortorya. Hokkado permited T.N. and M.Y., respectively, to use microprobe and gave valuable discussion. T.N. is indebted to Dr. H. Kagami, Mr. H. Asada, and Mrs. H. Yamawaku of Inst. for Thermal Spring Research, Okayama Univ. in their technical assistances. MrS. Yokoyama typed the manuscript. We acknowledge gratefully these persons.

\section{REFERENCES}

Aoki, K, and Prinz, M. (1974) Chromian spincls in lherzolite inclusions from Itinome-gata, Japan. Contrib. Mineral. Petrol, 46, 249-256.

Arculus, R.J. (1974) Solid-solution characteristics of spinels: pleonaste-chromite-magnetite compositions in some island arc basalts. Cannegie Inst. Washington Year Book, 73, 322-327.

(1978) Mineralogy and petrology of Grenada, Lesser Antilles island arc. Contrib. Mineral. Petrol, 65, 413-424.

Babkine, J., Conqere, F., Vilminot, J.C. and Phan, K.D. (1965) Les Spinelles des basaltes de
Monistrol d'Allier (chaine du Deves, HauteLoire). Bull. Soc. Franc. Miner. Crist, 88, 447445 .

Bence, A.E. and Albee, A.I. (1968) Empirical correction factors for the electron microanalysis of silicates and oxides. J. Geal., 76, 382-403.

Bryan, W.B. (1972) Mineralogical studies of submarine basalts. Carnegic Inst. Washington Year Book, 71, 396-403.

Carmichael, 1.S.E. (1967) The mineralogy of Thingunouli, a Tertiary volcano in Eastern Iceland. Am. Mineral., 52, 1815-1841.

Evans, B.W. and Wright, T.L. (1972) Composition of liquidus chromite from the 1959 (Kilauea Iki) and 1965 (Makaopuhi) eruptions of Kilauea volcano, Hawaij. Am. Mineval., 57, 217-230.

Green, D.H., Ringwood, A.E., Ware, N.G., Hibberson, W.O. and Mayor, A. (1971) Experimental petrology and petrogenesis of Apollo 12 basalts. Proc. Second Lunar Sci. Conf., 1, 601-615.

- Ringwood, A.E., Ware, N.G. and Hibberson, W.O. (1972) Experimental petrology and petrogenesis of Apollo 14 basalts. Proc. Thivd Lunar Sci. Conf., Geochim. Cosmochim. Acta, Suppl. 3, 1,197-206.

Gunn, B.M., Coy-Yll, R., Watkins, M.D., Abranson, E. and Nougier, J. (1970) Geochomistry of oceanite-ankaramite-basalt suito from East Island, Crozet Archipelago. Contrib. Mineral. Petrol., 28, 319-339.

Haggerty, S.E. (1977) Spinels and ilmenites in high pressure regimes: an empirical analysis. Extended abstracts for "The second Interantional Kimberlite Conference" Caynegie Inst. Washington.

(1979) Spinels in high pressure regimes. In: F.R. Boyd and H.O.A. Meyer (eds.) "Inclusions in Kimberlites and Other Volcanics" vol. 2, 183-196. Am. Geophys. Union.

Hill, R. and Roeder, P. (1974) The crystallization of spinel from basaltic liquid as a function of oxygen fugacity. J. Geol., 82, 709-729.

Irvine, T.N. (1965) Chromian spinel as a petrogenetic indicator, Part 1. Theory. Can. J. Farth Sci., 2, 648-672.

(1967) Chromian spinel as a petrologenetic indicator, Part 2. Petrologic applications. Can. J. Sci., 4, 71-103.

Kuroda, N. and Shiraki, K. (1975) Boninite and related rocks of Chichi-jima, Bonin Yslands, Japan. Rep. Fac. Sci., Shizuoka Univ, 10, 145-155.

Lowder, G.G. (1973) Late Cenozoic transitional alkali olivine-tholeiitic basalt and andesite from the margin of the Great Basin, southwest Utah. Bull. Geol. Soc. Am., 84, 2993-3012.

Myers, C.W., Bence, A.E., Papike, J.J. and Ayuso, 
R.A. (1975) Petrology of an alkali-olivine basalt sill from Site 169 of DSDP Leg 17: the Central Pacific. J. Geophys. Res., 80, 807-822.

Nagao, T. (1978) Two types of basalt series formed by the fractional crystallization of olivine tholeiitic magma-an example in San-in Pliocene basalts. MAGMA, 54, 8-13. (in Japarese).

Nehru, C.E., Prinz, M., Dowty, E. and Keil, K. (1974) Spinel-group minerals and ilmenite in Apollo 15 Rake Samples. Am. Mineral., 59, 1220-1235.

Onuma, K. (1963 a) Geology and petrology of Chokai volcano, northeastern Japan, Part I. Geology and petrogxaphy. J. Japan. Assoc. Min. Pet\%. Econ. Geol., 50, 1-20.

(1963 b) Ceolgy and petrology of Chokai volcano, northeastern Japan, Part II. Petrochemistry and petrogenesis (1). J. Japan Assoc. Min. Petr. Econ. Geol., 50, 235-244.

- (1964) Geology and petrology of Chokai volcano, northeastern Japan, Part III, petrochemistry and petrogenesis (2). I. Japan Assoc. Min. Petro. Econ. Geol., 51, 21-29.

Ridley, W.I., Rhodes, J.M. Jakes, P., Shih, C and Bass, M.N. (1974) Basalts from Leg 6 of the Deep Sea Drilling. J. Petrol, 15, 140-159.

Sato, H. (1977) Oxidation state of iron in samukito magma estimated from the composition of chromian spinel. Bull. Vol. Soc. Japan, Ser. 2, 22, 288-289. (in Japanese).

Sigurdsson, H. and Schilling, J.G. (1976) Spinels in
Mid-Atlantic Ridge basalts: chenistry and occurrence. Earth Planet. Sci. Lett., 29, 7-20.

Shiraki, K., Yusa, Y., Kuroda, N. and Ishioka, K. (1977) Chrome-spinels in some basalts from Guam, Mariana island arc. J. Geol. Soc. Japas, 83, 33-40. (in Japanese with English abstract) - Ohashi, F. and Kuroda, N. (1979) Chrome-spinels in a basanitic lava from Nanzaki volcano, Izu Peninsula. J. Japan Assoc. Min. Petro. Econ. Geol., 74, 114-121. (in Japanese with English abstract).

Steele, I.M. (1972) Chromian spinels from Apollo 14 rocks. Eanth Planet. Sci. Lett. 14, 190-194.

Takannura, H. (1973) Petrographical and petrochemical studies of the Cenozoic basaltic rocks in Chugoku province. Rept. Eayth Sci., Hiroshima Uniw. 18, 1-167. (in Japanese with English abstract)

Tazaki, K. (1975) Chromian spinels in picrite basalts from Mineoka Tectonic Belt, Boso Peninsula, central Japan J. Geol. Soc. Japan, 81, 399-406. (in Japanese with English abstract).

Thompson, R.N. (1973) Titanian chromite and chromian titanomagnetite from a Snake River plain basalt, a terrestrial analogue to lunar spinels. Am. Mineral., 58, 826-830.

Varne, R. and Brown, A.V. (1978) The geology and petrology of the Adamsfield ultramafic complex, Tasmania. Contrib. Mineval. Petrol., 67, 195-207.

\section{日本列島のニ・三のアルカリ玄武岩，カルクアルカリ安山岩の クロムスピネルの結晶作用経路}

\section{永尾 隆忘・山元 正継・大沼 晃助}

三朝地城の鮮新世アルカり玄武岩々鳥海火山のカルクアルカリ安㛧のクロムスピネルは，従来報告されて いる密弧の火山岩のbのにくらべ $\mathrm{Al}_{2} \mathrm{O}_{3}$ 量に富んだものである。

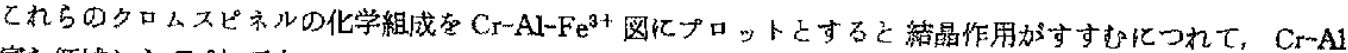

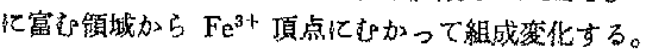

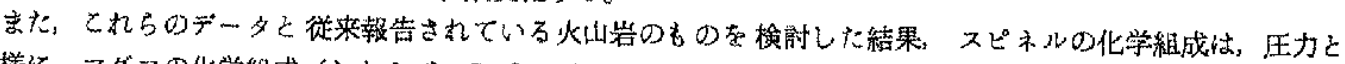

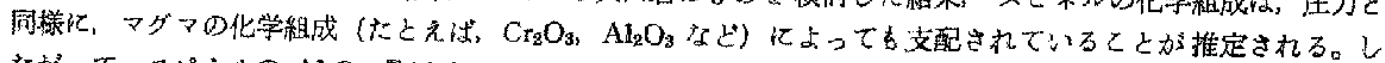

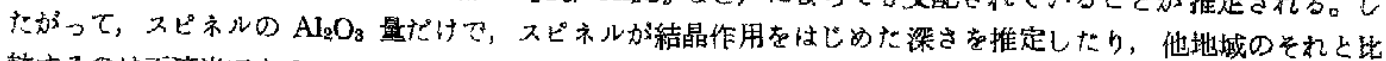
䑤するの仿不適当である。

Misasa 三朝

Chokai 舅海 